\section{BRITISH LIZARDS.}

WE are glad to welcome this companion volume to the author's excellent work on British snakes, for with the two together the amateur naturalist will learn practically all that he wants to know with regard to the reptiles of our islands. Not that these works are by any means exclusively for amateur naturalists, as there is much matter in both which cannot fail to interest their professional brethren. If Dr. Leighton can be induced to treat the amphibians in a similar manner, we shall have a complete account of the life-history of all the British terrestrial cold-blooded vertebrates.

The author's mode of procedure is very thorough. After giving the leading characteristics of lizards in general, he describes in some detail their anatomy, and then proceeds to deal, seriatim, with the five British representatives of the group. The external features of each are illustrated by reproductions from photographs, of the excellence of which our readers have an opportunity of judging for themselves from the accompanying specimen.

occur at regular intervals of two scales' length, such spaces coinciding with the lengths of the caudal muscle; and the author is of opinion that the superficial structures have much more to do with determining the fracture than have the septa in the caudal vertebræ.

Concise, exact, and at the same time interesting is our verdict with regard to this admirable little volume.

R. L.

\title{
THE EDUCATION OF JAPANESE NAVAL
}

\section{OFFICERS.}

$O \mathrm{~N}$ reference to the second article on "Science in the Navy," published in Nature of last year, it will be found that the gist of that article was the condemnation of the over-specialisation of officers, accompanied by remarks in favour of the interchangeability of their duties, the practice of the German Navy being brought forward as an existing evidence in support of such views.

Increased support of these views will be found in a valuable lecture which was recently delivered by Lieut.Commander K. Sato, of the Imperial Japanese Navy, at the Royal United Service Institution, on "The Education of Japanese Naval Officers of the Executive Branch," in which that officer shows that the "Eastern nation," thought at one time to be "too bookish," is by its methods of education making its naval officers eminently practical men with a good grounding of general and scientific knowledge.

The lecturer admitted that his country had fairly followed Great Britain's footsteps in this important matter of education, and had duly profited by the instruction of her officers, but modestly hinted that perhapa in one or two small particulars they had gone "one better" than we had. Here it is encouraging to note

Fig. I. - Female of the Common Viviparous Lizard. (From Leighton's " Life-History of British Lizards.")

It is a common belief that reptiles are totally wanting in Ireland; this, however, Dr. Leighton shows to be an error, as the common viviparous lizard occurs in that island, where, however, it is the sole representative of its order. How it got there, to the exclusion of its brethren, he attempts to show. In the later chapters of the book the author has gone very carefully into the local distribution of lizards in our islands, with results of considerable interest; and in order that readers may record new observations for themselves a few tabulated blank pages are appended. Horticulturists should pay special attention to the author's statements as to the great value of the slow-worm as a slug-exterminator. The enlarged diagrams of the "squamation" of the head afford an easy and exact method of identifying the British species of lizards.

Special interest attaches to Dr. Leighton's investigations with regard to the phenomenon of tail-fracture in lizards. It is pninted sut that such lines of fracture

1 "The Life-History of British Lizards, and their Local Distribution in the British Islands." By G. R. Leighton. Pp. xiv $+2{ }_{4}$; plates. (Edin. burgh: G. A. Morton, tgo3.) Price 5s. net. that the gallant chairman, with his life-long education in the traditions of our long established Navy, said that there were many things this country could learn from the Japanese Navy-encouraging because we believe that this power to see good in others where it really exists and determination to profit by the same is a ruling spirit amongst our officers.

Whilst giving due encouragement to the specialist officer, it is the constant effort of the Japanese to produce all round officers which is so striking, and one would think they had adopted the following as their maxim :- "Inadvertence is no excuse for the nonperformance of any duty, for, it is the duty of an officer to make himself acquainted with the detail of every duty he may be called upon to perform."

This is a high standard, and not many fully attain thereto, but it will hardly be denied that it should be the aim of every officer, whilst those who regulate education should do all in their power to keep the road open with efficient aids by the way. Interchangeability is a very promising road to such a goal.

Another point which this lecture brings out clearly NO. I795, VOL. 69] 